\title{
PENGARUH PENGELUARAN DANA PROGRAM KEMITRAAN USAHA DAN RELAWAN TERHADAP PENGHIMPUNAN DANA ZAKAT (Studi Lembaga Amil Zakat Baitulmaalku Karawang Periode 2017 - 2019)
}

\author{
Muhammad Hamdan 'Ainulyaqin', Hendro Lutin² \\ 1 Universitas Pelita Bangsa, hamdanainulyaqien@pelitabangsa.ac.id \\ 2 Universitas Pelita Bangsa, hendrolutin44@gmail.com
}

\section{Article history: \\ Received : 17/03/2021 \\ Revised : $17 / 03 / 2021$ \\ Accepted: 02/04/2021}

A R T I C L E I N F O

\section{Key words:}

Business Partnership Program; Volunteer; The Collection of Zakat

DOI:

Doi.org/10.37366/jespb.v6i01.175

\section{A B S T R A C T}

The very positive potential of zakat in Indonesia triggers competition betweem many amil zakat institutions to gain muzakkie's trust. In zakat management institutions the activities of collecting (fundraising) zakat funds are very important for amil zakat institutions to cary out institutional activities. This study aims to analyze the effect of business and volunteer partnership programs on the collectionbof zakat funds. Volunteer and business partnership program as an independent variable and zakat fund collection as the dependent variable. The object of research at the Baitulmaalku Karawang amil zakat intitute.

The research method uses quantitative methods of data collection with secondary data in the form of financial reports. The subject of this research is the Baitulmaalku Karawang amil zakat institution. The number of samples is 36 , the analysis method used is multiple linear regression analysis, classical assumption test, and hypothesis testing. The analysis results obtained partially, the business partnership program has a value of 4,214 and a significance value of 0,00 and volunteeers have a t value of 1,616 and a significance value of 1,16. simultaneously get the $F$ value count 122,528 and a significance value of 0,00 . The business partnership program has a positive and significant effect on the collection of zakat fund. Whilw volnteers do not have a positive and significant effect on the collection of zakat funds. Simultaneously partnership of business and volunteers affects the collection of zakat funds.

\section{A B S T R A K}

Potensi zakat di Indonesia yang sangat positif memicu persaingan antara banyak lembaga amil zakat untuk meraih kepercayaan muzakki. Dalam lembaga pengelolaan zakat Kegiatan penghimpunan dana (fundraising) merupakan hal yang sangat penting bagi lembaga pengelola zakat untuk menjalankan aktifitas lembaga. Penelitian ini bertujuan untuk menganalisis pengaruh program kemitraan usaha dan relawan terhadap penghimpunan dana zakat. Program kemitraan usaha dan relawan sebagai Variabel independen dan penghimpunan dana zakat sebagai variabel dependen. Objek penelitian di lembaga amil zakat baitulmaalku Karawang.

Metode penelitian menggunakan metode kuantitatif pengambilan data dengan data skunder berupa laporan keuangan. Subjek penelitian ini di Laz Baitulmaalku Karawang. Jumlah sampel sebanyak 36, metode analasisi yang digunakan yaitu analisis regresi linear berganda, uji asumsi klasik dan Uji hipotesis. Hasil analisis yang diperoleh Secar parsial, Program kemitraan usaha memimiliki nilai thitung sebesar 4,215, serta nilai signifikansi 0,00, dan 
Relawan memiliki nilai thitung sebesar 1,616, serta nilai signifikansi 1,16. Secara simultan didapat nilai Fhitung 122,528, dan nilai signifikasi 0,00. Program kemitraan usaha perpengaruh secara posistif dan signifikan terhadap penghimpunan dana zakat, Sedangkan Relawan tidak berpengaruh secara positif dan signifikan terhadap penghimpunan dana zakat. Secara bersama (simultan) program kemitraan usaha dan relawan berpengaruh terhadap penghimpunan dana zakat.

\section{PENDAHULUAN}

Dalam hukum Islam, zakat merupakan kewajiban yang harus dilaksanakan bagi orangorang yang telah memenuhi syarat. Pentingnya kewajiban zakat ini sederajat dengan pentingnya kewajiban shalat dan memiliki kaitan yang erat antara keduanya. Shalat membentuk jiwa bersih, sedangkan zakat merupakan amalan yang berdimensi sosial kemasyarakatan yang didasari oleh jiwa yang bersih. Membayar zakat merupakan salah satu dari lima sendi Islam atau rukun Islam, zakat sekaligus menjadi salah satu di antara kewajiban-kewajiban pokok dalam Islam (mardani, 2016).

Pada masa Rasulullah Saw dan para Sahabat, zakat merupakan salah satu instrumen sebagai sumber pendanaan negara yang sangat berperan aktif dalam membangun ekonomi untuk kesejahteraan umat. Setidaknya terdapat beberapa aspek terkait dengan pelaksanaan kewajiban membayar zakat diantaranya. Pertama aspek moral dimana pada aspek ini diharapkan setiap individu dapat menghilangkan ketamakan atas kecintaan terhadap harta yang dimilikinya sehingga tumbuh rasa bersyukur atas apa yang sudah dimiliki dan tidak sungkan untuk berbagi harta terhadap sesama. Kedua aspek sosiologis bertujuan untuk memeratakan kesejahteraan dari orang kaya kepada orang miskin secara adil dan mengubah penerima zakat menjadi pembayar zakat. ketiga aspek ekonomi artinya bahwa zakat mempunyai misi meratakan kesejahteraan dan kebahagian dalam bidang ekonomi lebih jauh dapat berperan serta dalam membangun perekonomian mendasar yang bergerak langsung ke sektor ekonomi lemah (mursyidi, 2006).
Potensi zakat di Indonesia sendiri menurut berbagai kajian yang dilakukan menunjukan prospek yang sangat menggairahkan. Bahkan Asian Development Bank (ADB) sempat menyebutkan angka Rp. 27 triliun, sebuah angka yang fantastis. dari data yang ada ternyata memang pada tahun 2007 terkumpul di BAZNAS Rp. 450 miliar, tahun 2008 terkumpul Rp. 920 miliar, 2009 menjadi Rp. 1,2 triliun, dan tahun 2010 menjadi Rp 1,5 triliun. Menurut hasil riset BAZNAS dengan FE IPB, potensi zakat mencepat 3,4\% dari PDB atau setara dengan Rp. 217 triliun. Data pusat kajian strategis kajian badan amil zakat di Indonesia masih rendah pada 2016, tercatat zakat masuk Rp. 5 triliun jumlah ini hanya 1 persen dari potensi zakat di Indonesia. Data tersebut mengindikasikan bahwa persoalan zakat merupakan hal yang urgen untuk dikaji. dengan prediksi semacam itu, zakat akan mampu memberikan kontribusi yang sangat signifikan bagi proses kesejahteraan umat. Dengan zakat yang dicapai saat ini saja dapat dilihat bahwa banyak lembaga amil zakat yang mulai mampu menyediakan berbagai fasilitas yang sifatnya gratis bagi masyarakat, terutama masyarakat tidak mampu, sejak dari ambulan gratis, beasiswa, hingga rumah sakit gratis atau murah. Karena itu dengan berbagai tantangan zakat sebenarnya memberikan peluang bagi pengembangan umat yang sangat menjanjikan (mardani, 2016).

Melihat potensi zakat di Indonesia yang sangat positif memicu persaingan di antara banyak lembaga amil zakat untuk meraih kepercayaan para muzakki untuk menyalurkan dananya. Peran Badan Amil Zakat (BAZ) dan Lembaga Amil Zakat (LAZ) dalam meningkatkan pertumbuhan ekonomi sangat signifikan, terbukti dengan tumbuhnya pengelolaan zakat, dengan pola distribusi pada arah pengembangan produktifitas Mustahik. Dimana 
dalam pengumpulan Zakat muzakki dapat menghitung sendiri atas kewajibanya, dalam hal ini jika muzakki tidak bisa menghitung sendiri kewajiban terutama kewajiban membayar Zakat, Muzakki dapat meminta kepada pengelola Badan Amil Zakat atau Lembaga Amil Zakat untuk menghitungkanya. Adapun manfaat zakat dapat memperbaiki kondisi masyarakat baik dari segi moril maupun materil, jika pengelolaanya yang sangat baik, dapat menghindari kesenjangan sosial, meningkatkan keimanan masyarakat serta dapat menumbuhkan rasa kegotongroyongan untuk saling membantu sesama. Potensi zakat di Indonesia yang sangat positif memicu persaingan di antara Lembaga Amil Zaakat (LAZ) untuk menumbuhkan rasa kepercayaan Muzakki untuk menyalurkan dananya.

Salah satu Lembaga Amil Zakat yang ikut berkhidmat dalam membantu perekonomian indonesia yaitu LAZ Baitulmaalku yang didirikan pada tahun 2017, yang awalnya mengelola program event dakwah soisal. Selanjutnya dikukuhkan oleh Mentri Agama Republik Indonesia sebaagai Lembaga Amil Zakat berskala kabupaten melalui SK No. 1676 tahun 2019. Sesuai dengan telah berlakunya Undang-undang Zakat Nomor 14 tahun 2014, dan keputusan Mentri Agama Republik Indonesia Nomor 333 tahun 2015. Tugas terpenting dari lembaga pengelola zakat yaitu melakukan penghimpunan dan pendistribusian dana zakat dari masyarakat secara berkesinambungan melalui forum dan media. Sehingga pengaruh program dan relawan menjadi hal yang sangat penting dalam pengumpulan dana zakat.

Pelaksanaan program kemitraan usaha dan relawan Laz Baitulmaalku merupakan langkah yang dilakukan dengan bentuk kerjasama antara lembaga dengan mustahik, dimana mustahik diberikan bantuan dana dari program Dhuafa berdaya untuk membangun usaha dan pelatihan serta diberi bimbingan dan pengawasan dalam usahanya. Tujuan dari program tersebut adalah untuk menjadikan mustahik lebih mandiri dan tujuan yang lebih utamanya yaitu agar Mustahik bisa menjadi muzakki di kemudian hari. Relawan mempunyai pengaruh yang sangat dibutuhkan baik dalam mensosialisasikan ataupun penghimpunan dana zakat bagi lembaga. Dengan adanya program kemitraan usaha dan relawan dapat memperluas sosialisasi agar masyarakat tertarik dalam membayar zakat. Berdasarkan uraian diatas, penulis tertarik melakukan penelitian ini yaitu untuk mengetahui fakta apa saja yang menjadikan program kemitraan usaha dan relawan dapat berpengaruh dalam penghimpunan dana zakat. Khususnya di Lembaga Amil Zakat Baitulmaalku Karawang.

\section{Rumusan Masalah}

Berdasarkan uraian pada latar belakang yang telah dijabarkan di atas, maka penulis merumuskan masalah sebagai berikut:

1) Apakah pengeluaran dana program kemitraan usaha berpengaruh terhadap penghimpunan dana zakat di Laz Baitulmaalku?

2) Apakah pengeluaran dana Relawan berpengaruh terhadap penghimpunan dana zakat di Laz Baitulmaalku?

3) Apakah pengeluaran dana program kemitraan usaha dan relawan secara bersamaan berpengaruh terhadap penghimpunan dana zakat di Laz Baitulmaalku?

\section{Tujuan Penelitian}

Berdasarkan rumusan masalah di atas, maka penelitian ini bertujuan sebagai berikut:

1) Untuk menganalisis pengaruh pengeluaran dana Program Kemitraan Usaha terhadap penghimpunan dana zakat di Laz Baitulmaalku.

2) Untuk menganalisis pengaruh pengeluaran dana relawan terhadap penghimpunan dana zakat di Laz Baitulmaalku.

3) Untuk menganalisis pengaruh pengeluaran dana Program Kemitraan Usaha dan Relawan terhadap penghimpunan dana zakat di Laz Baitulmaalku. 


\section{TINJAUN TEORITIS}

\section{Kemitraan Usaha}

Menurut undang-undang republik Indonesia no.9 tahun 1995 kemitraan adalah kerjasama usaha antara usaha kecil dan usaha menengah atau usaha besar disertai pembinaan dan pengembangan oleh usaha menengah atau usaha besar dengan memperhatikan prinsip saling memerlukan,saling memerlukan, saling memperkuat dan saling menguntungkan. Kemitraan usaha adalah jalinan kerjasama usaha yang saling menguntungkan antara pengusaha kecil dengan pengusaha menengah atau besar (perusahaan mitra) disertai dengan pembinaan dan pengembangan oleh pengusaha besar dengan memperhatikan prinsip saling menguntungkan (Sutawi, dalam Yuliani, 2004:11). Sedangkan menurut Wie (1992:3) mengatakan, kemitraan merupakan kerjasama usaha antara perusahaan besar atau menengah yang bergerak di sektor produksi barang-barang maupun di sektor jasa dengan industri kecil berdasarkan atas asas saling membutuhkan, saling memperkuat, dan saling menguntungkan.

\section{Relawan}

Relawan adalah seseorang yang secara sukarela (uncoeced) menyumbangkan waktu, tenaga, pikiran, dan keahliannya untuk menolong orang lain (help other) dan sadar bahwa tidak akan mendapatkan upah atau gaji atas apa yang telah disumbangkan. Menjadi relawan adalah salah satu aktifitas yang dapat dilakukan oleh seluruh lapisan masyarakat sebagai wujud kepedulian dan komitmennya terhadap sebuah visi tertentu (Galuh,dalam Departemen Pekerjaan Umum). Slamet (2009) mengemukakan relawan adalah orang yang tanpa dibayar menyediakan waktunya untuk mencapai tujuan organisasi,dengan tanggung jawab yang besar atau terbatas, tanpa atau dengan sedikit latihan khusus, tetapi dapat pula dengan latihan yang sangat intensif dalam bidang tertentu, untuk bekerja sukarela membantu tenaga professional.

\section{Zakat}

Zakat merupakan kata dasar dari zaka yang berarti berkah, tumbuh, dan baik. Menurut lisan Al Arab kata zaka mengandung arti suci, tumbuh, berkah dan terpuji. Zakat menurut istilah fiqh adalah sejumlah harta tertentu yang harus diserahkan kepada orang-orang yang berhak menurut syariat ALLAH SWT (Qardawi,1991). kata zakat dalam terminologi al-qur"an sepadan dengan kata sedekah. Secara etimologis zakat mempunyai beberapa arti, yaitu berkembang, berkah,dan kebaikan yang banyak.Disebut demikian karena jika harta dikeluarkan zakatnya, harta tersebut akan menjadi tumbuh dan berkah serta menjadi lebih baik (Mardani, 2016).

\section{Kerangka Pikir}

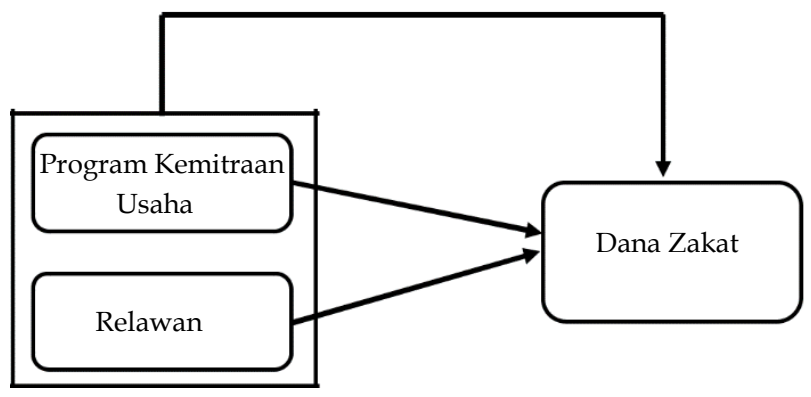

\section{Gambar 1. Kerangka Pikir}

Dari gambaran diatas dapat diajukan hipotesisnya sebagai berikut:

1) Pengaruh program kemitraan usaha terhadap penghimpunan dana zakat.

Ha : Program kemitraan usaha berpengaruh positif terhadap penghimpunan dana zakat

H0 : Program kemitraan usaha tidak berpengaruh positif terhadap penghimpunan dana zakat

2) Pengaruh relawan terhadap menghimpunan dana zakat.

Ha : Relawan berpengaruh positif terhadap penghimpunan dana zakat

H0 : Relawan tidak berpengaruh positif terhadap penghimpnan dana zakat 
3) Pengaruh Program kemitraan usaha dan relawan terhadap menghimpunan dana zakat.

Ha : Program kemitraan usaha dan relawan berpengaruh positif terhadap penghimpunan dana zakat

H0 : Program kemitraan usaha dan relawan tidak berpengaruh positif terhadap penghimpunan dana zakat

\section{METODE PENELITIAN}

Pendekatan yang digunakan pada penelitian ini adalah kuantitatif dan jenis penelitiannya adalah jenis penelitian lapangan dengan teknik dokumentasi dan observasi dalam pengambilan data. Penelitian ini dilakukan di Lembaga Amil Zakat Baitulmaalku Karawang. Populasi dan sampel yang dipake adalah laporan keuangan Lembaga periode 2017-2019 dengan menggunakan metode analisis berupa regresi linier berganda.

\section{HASIL DAN PEMBAHASAN}

\section{Uji Analisis Deskriptif}

Hasil Uji variabel program kemitraan usaha mempunyai nilai mean 40,32399 dan standar deviasi (std deviation) 101,796483. Hal ini berarti nilai mean lebih kecil dari standar deviasi, sehingga mengidentifikasikan bahwa hasil yang kurang baik. Sebab standar deviasi merupakan pencerminan penyimpangan yang sangat tinggi, sehingga penyebaran data menunjukan hasil yang tidak normal dan menyebabkan bias. Nilai minimal penghimpunan dana zakat sebesar 1000 dan nilai maksimum 465.629. Sedangkan variabel relawan mempunyai nilai mean sbesar 60.611 dengan standar deviasi (std deviation) sebesar 16.680 yang artinya bahwa nilai mean lebih besar dari pada standard deviasi, sehingga mengidentifikasikan bahwa hasil yang cukup baik, hal tersebut dikarenakan standar deviasi adalah pencerminan penyimpangan yang sangat tinggi, sehingga penyebaran data menunjukan hasil yang normal dan tidak menyebabkan bias. Nilai minimalnya sebesar 100 dan nilai maksimumnya sebesar 300. Sedangkan variabel Dana zakat diperoleh bahwa nilai mean adalah 83.56930 dengan standar (standar deviation) sebesar 20.54809 yang berarti nilai mean lebih besar dibandingkan dengan standar deviasi, sehingga mengidentifikasikan hasil sebaran data yang cukup baik. Hal tersebut dikarenakan standar deviasi adalah pencerminan penyimpangan yang sangat tinggi, sehingga penyebaran data menunjukan hasil yang normal dan tidak menyebabkan bias. Nilai minimumnya sebesar 2.000 dan nialai maksimumnya sebesar 9312517.

\section{Uji Normalitas}

Dari hasil pengujian diketahuai bahwa nilai sig sebesar 0,302 nilai ini dibandingkan dengan 0,05, maka nilai variabel dana zakat sebesar 0,302 lebih dari 0,05 shingga variabel dana zakat normal.

\section{Uji Multikolonieritas}

Hasil perhitungan nilai tolerance menunjukan tidak ada variabel independen yang memiliki tolerance kurang dari 0,10 hasil perhitungan nilai Variance inflation factor (VIF) juga menunjukan hal yang sama tidak ada satu variabel independen yang memiliki nilai VIF lebih dari 10. Berdasarkan coefficient pada gambar diatas maka dapat diketahui bahwa nilai VIF adalah 7,415 (variabel kemitraan usaha) dan sebesar 7,415 (variabel relawan). Sehingga kesimpulanya bahwa variabel independen terbebas dari asumsi klasik multikoloniaritas karena hasilnya lebih kecil dari 10 .

\section{Uji Autokorelasi}

Hasil uji autokorelasi Nilai Durbin Watson sebesar 1.929. Berdasarkan hasil pengujian dengan nilai tabel durbin watson pembanding diketahui hasil uji autokorelasi du=1,724; $\mathrm{dl}=1,236 \mathrm{dan} 4$-du= 2,276 Dengan nilai tabel pada tingkat signifikansi $5 \%$, jumblah sample 36 (n) dan jumlah variabel independen $2(\mathrm{k}=2)$, nilai Durbin Watson dari hasil analisis regresi sebesar 1.929. Dengan demikian nilai durbin Watson berada pada interval 1,724 sampai dengan 2,276 $(1,724<1.929<2,276)$ sehingga dapat dipastikan bahwa model regresi linier berganda tersebut tidak terjadi gejala autokorelasi.

\section{Analisis Regresi Linier Berganda}

Berdasarkan hasil dari coefficients dapat dikembangkan dengan menggunkan model persamaan regresi linier berganda sebagai berikut: 
Dana zakat $=\mathrm{a}+\mathrm{b} 1$ kemitraan usaha $+\mathrm{b} 2$ relawan

Apabila hasil perhitungan disubsitusikan, maka akan diperoleh nilai sebagai berikut:

Penghimpunan dana zakat $(\mathrm{Y})=0,898+0,219(\mathrm{X} 1)+$ $1,207(X 2)$

1) Konstanta sebesar 0,898 artinya jika program kemitraan usaha dan relawan tidak ada maka penghimpunan dana zakat sebesar 0,898.

2) Koefisien regresi $X 1$ sebesar 0,219 artinya setiapa kenaikan satu satuan program kemitraan usaha meningkatkan penghimpunan dana zakat sebesar 0,219. Dan sebaliknya setiap penurunan satu satuan program kemitraan usaha akan menurunkan penghimpunan dana zakat sebesar 0,219 .

3) Koefisien regresi $X 2$ sebesar 1,207 artinya setiap kenaikan satu satuan relawan akan meningkatkan penghimpunan dana zakat sebesar 1,207. Dan sebaliknya setiap penurunan satu satuan relawan akan menurunkan penghimpunan dana zakat sebesar 1,207. Tanda (+) menunjukan arah hubungan yang searah sedangkan tanda (-) menunjukan arah hubungan yang berbanding terbalik antara variabel independen $(X)$ dengan variabel dependen $Y$.

\section{Uji T}

Berdasarkan uji $\mathrm{t}$ diperoleh nilai ttabel variabel Program kemitraan usaha sebesar 1,986 (diperoleh dengan cara mencari nilai $\mathrm{df}=\mathrm{n}-1=36-1=34$ dan nilai $\alpha=5 \%$ dibagi menjadi dua yaitu $5 \% / 2=0,025$ ) dan nilai t hitung sebesar 4,215. Karena nilai thitung $>$ t tabel yaitu 4,215 $>1,986$ serta nilai sig 0,00 <0,05, maka dapat disimpulkan variabel program kemitraan usaha berpengaruh signifikan terhadap penghimpunan dana zakat di Lembaga Amil Zakat Baitulmaalku. Sedangkan nilai $t$ tabel variabel Relawan 1,986 (diperoleh $\mathrm{n}-1=36-1=34$ dan nilai $a=5 \%$ dibagi menjadi dua yaitu $5 \% / 2=0,025$ ) dan nilai $\mathrm{t}$ hitung sebesar 1,616. karena nilai $\mathrm{t}$ hitung $<\mathrm{t}$ tabel yaitu 1,616 < 1,986 serta nilai sig 1,16>0,05, maka dapat disimpulkan variabel pengeluaran dana Relawan tidak berpengaruh signifikan terhadap penghimpunan dana zakat di Lembaga Amil Zakat Baitulmaalku.

\section{Uji F}

Berdasarkan hasil pengujian didapat nilai $\mathrm{F}$ hitung 122,528 dan $\mathrm{F}$ tabel sebesar 2,69. Maka F hitung > F tabel yaitu $122,528>2,69$. hal ini menunjukan bahwa semua variabel independen yaitu program kemitraan usaha dan relawan berpengaruh secara simultan (bersama-sama) terhadap penghimpunan dana zakat di Lembaga Amil Zakat Baitulmaalku. Serta berdasarkan nilai signifikasi 0,00 yang lebih kecil dari nilai 0,05, maka 0,00<0,05 yang berarti Program kemitraan usaha dan Relawan berpengaruh secara simultan terhadap Penghimpunan dana zakat di Lembaga Amil Zakat Baitulmaalku.

\section{KESIMPULAN}

Berdasarkan penelitian yang dilakukan peneliti tentang Pengaruh Pengeluaran Dana Program Kemitraan Usaha Dan Relawan Terhadap Penghimpunan Dana Zakat (Studi Kasus Laporan Keuangan Lembaga Amil Zakat Baitulmaalku Periode 2017 sampai 2019) dapat disimpulkan diantaranya:

\section{1) Secara parsial}

a. Untuk variabel Program kemitraan usaha dari hasil perhitungan yang telah dilakukan peneliti, diperoleh nilai $t$ hitung $>\mathrm{t}$ tabel yaitu 4,215 > 1,986. Maka dapat disimpulkan bahwa variabel program kemitraan usaha berpengaruh signifikan terhadap penghimpunan dana zakat di Lembaga Amil Zakat Baitulmaalku.

b. Sedangkan variabel Relawan sesuai perhitungan yang telah dilakukan peneliti, diperoleh nilai $\mathrm{t}$ hitung $<\mathrm{t}$ tabel yaitu 1,616 <1,986. Maka dapat disimpulkan variabel Relawan tidak berpengaruh signifikan terhadap penghimpunan dana zakat di Lembaga Amil Zakat Baitulmaalku.

\section{2) Secara simultan}

Hasil dari analisis yang dilakuakan peneliti didapat nilai Fhitung 122,528 dan Ftabel sebesar 2,69. Maka Ftabel > Ftabel yaitu 122,528 > 2,69. Dan nilai signifikasi 0,00 yang lebih kecil dari nilai 0,05, maka 0,00<0,05 yang berarti Program kemitraan usaha dan Relawan berpengaruh 
secara simultan terhadap Penghimpunan dana zakat di Lembaga Amil Zakat Baitulmaalku.

\section{DAFTAR PUSTAKA}

Any Widiasmara.2018. Analisis Efektifitas Program Kemitraan Dan Bina Lingkungan PT INKA Pada UMKM. Jurnal.

Asep, heri. 2017. Faktor - Faktor yang Mempengaruhi Hubungan Kemitraan Antara Petani Budidaya Jamur Tiram Dengan Cv.Argo Corporation. Jurnal.

Benny Andika. 2015. Implementasi Program Kemitraan Dan Bina LIngkungan Pada BUMN. Jurnal.

Darmiyanti. 2008. Pola Kerjasama Antar Lembaga Amil Zakat Infak dan Shodaqoh, skripsi.

Imam Ghozali. 2013. Aplikasi Analisis Multivariate Dengan IMB SPSS 23. Semarang: Universitas Diponegoro.

Ismail Nawai. 2017. Figh Muamalah Klasik dan kontemporer. Bogor: Ghalia.

Mardani. 2016. Hukum Islam zakat, sedekah, infak dan wakaf. Bandung: Citra aditya bakti.

Molek, Arum, Nanik, 2017. Peranan Program Kemitraan Dan Bina Lingkungan Dibidang Pendidikan Dan Pengembangan Usaha. Jurnal.
Muhamad. 2008. Metodologi Ekonomi Islam. Jakarta: Rajagrafindo.

Mursyidi. 2006. Akuntansi Zakat Kontemporer. Bandung: Remaja Rosdakarya.

Nilda susilawati, 2018. Pola Kemitraan Inisiatif Zakat Indonesia Cabang Bengkulu. Jurnal.

Novi Purwanti.2019. Program Kemitraan Lembaga Amil Zakat Di Lembaga Inisiatf Zakat Indonesia cabang Bengkulu. Skripsi.

Putri Amalia Zain. 2018. Peran Relawan Sosial Dalam Mendampingi Anak Asuh. Skripsi

Ria Fitria. 2015. Analisis Pelaksanaan Program Kemitraan Dalam Rangka Pemberdayaan UKM. Jurnal.

Sry Lestari Dewi. 2019. Peran Relawan Dalam Penghimpunan dana ZIS Di Lembaga Amil Zakat Inisiatif Zaakat Indonesia Cabang Riau. Skripsi.

Susilawati ambar teguh. 2004. Kemitraan dan modelmodel pemberdayaan. Yogyakarta: Gaya media.

Yunidia Niken.2015. Program Kemitraan Dan Bina Lingkungan Sebagai Strategi Pembentukan Citra Perusahaan Sebagai CSR PT Petrokimia Gresik. Jurnal. 